\title{
Mn-Cr ばね鋼の恒温変態による機械的性質
}

\author{
上野学・内山郁・星野明彦*
}

\section{1. 緒言}

ばね鋼は車輛の振動エネルギーを吸収するために用い られるもので，特殊鋼の中でも，てのば徐の占める生 産高も大きく，今後共增大していくであろう。ばねに打 いては, 設計はもちろんのてと材料の選択及び熱処理作 業が性能を左右する因子となる。それにも拘ず，ばね龬 の熱処理に関する研究報告は他の鋼種に関するものほど 見受けられないが，最近のばね材の大型化に伴い耐久才 の点から焼入性が重要視されるようになり, JIS 規格に 新たに $\mathrm{Mn}-\mathrm{Cr}$ 鋼の SUP 9 及び B の添加によって更に 焼入性を向上させたSUP 11 が追記されたてとより考え てもばね鋼の焼入性が不完全焼入による疲学限の低下゙1 を避ける方向に進んでいるととは明らかである。 $\mathrm{Mr}^{-}$ Cr ばね鋼の熱処理に関する資料は少なく $\mathrm{H}$-band のみ で, 恒温変態曲線図がないため, 先ず恒温変態曲線図を 作成した後，その図に基いて各温度で得られた変態主成 物の機械的性質について調べた。

\section{2. 実験方法}

\section{1 供 試 材}

実験に用いた試材の化学組成は表 1 亿示されている。 表 $1 \mathrm{Mn}-\mathrm{Cr}$ 鋼の化学組成

\begin{tabular}{c|c|c|c|c|c|c|c}
\hline $\mathrm{C}$ & $\mathrm{Si}$ & $\mathrm{Mn}$ & $\mathrm{P}$ & $\mathrm{S}$ & $\mathrm{Cr}$ & $\mathrm{Ni}$ & $\mathrm{Cu}$ \\
\hline 0.54 & 0.25 & 0.88 & 0.010 & 0.013 & 0.85 & 0.08 & 0.19 \\
\hline
\end{tabular}

尚ての鋼のオーステナイト粒度は $925^{\circ} \mathrm{C}$ での渗炭加 熱後ピクリン酸窗触により求めた所 No.6 であった。

\section{2 恒温变態曲線図}

恒温変態曲線図の作成にあたり上記の化学組成を有す る $17 \mathrm{~mm} \psi$ の丸棒を研削により $10 \mathrm{~mm}$ 角とし, 次いで $5 \mathrm{~mm}$ 厚に切断した $10 \times 10 \times 5$ の小陚片を多数用意し た。オーステナイト化 $\left(850^{\circ} \mathrm{C} \times 30 \mathrm{~min}\right)$ 後, $750^{\circ} \mathrm{C}$ 以下 $300^{\circ} \mathrm{C}$ までの $50^{\circ} \mathrm{C}$ 毎の各温度に保持された金属 浴 $(\mathrm{Pb}-\mathrm{Sn})$ 中に乙れ等の小陚片を急冷し, 所定時間恒 温保持を行って後順次金属浴より引上げ食塩水中に急冷

\footnotetext{
* 金属材料技術研究所
}

して組織定着を行った。変驡進行状況を調べるには，前 述の如く処理した各試料について硬度（ロックウェル・ C) 測定を行うと共に lineal analysis 法によって変態率 を求めるてとにより、保持時間一変態率の図を描き, 各 温度に扔ける変態開始・完了点在求めると共に25, 50, $75 \%$ 変態点も求めた。

\section{$2.3 \mathrm{Ms}$ 点}

マルテンサイト反応を調べるには，恒温変態曲線の際 に使用したものと同一の試料を用いて， Greninger一 Troiano 法に基いて Ms 点起求めた。オーステナイト化 同様に $850^{\circ} \mathrm{C} \times 30 \mathrm{~min}$ とし, 最初 $340^{\circ} \mathrm{C}$ 以下の種々 の温度に恒温保持されている浴 (金属或は油) 中に急冷 し $30 \mathrm{sec}$ 保持後次いて Ms 点以上の温度で焼戻を行うた め $400^{\circ} \mathrm{C}$ の金属浴中で $10 \mathrm{sec}$ 焼戻加熱を行って後水冷 して lineal analysis 法より焼戾マルテンサイト量を測 定した。

\section{3. 実験結果及び考察}

\section{1 恒温変態曲線図}

$850^{\circ} \mathrm{C} \times 30 \mathrm{~min}$ オーステナイト化後各温度で恒温変驡 を行った時に得られた保持時間一変態率図より求めた変 驡開始及び完了点より $\mathrm{Mn}-\mathrm{Cr}$ 鋼の恒温変態曲線図を作 成し図 1 に示した。

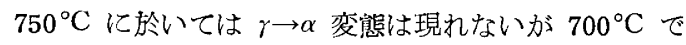
は比較的長時間後に, 先ずオーステナイト粒界に初析フ ェライトが析出後パーライトが析出して来る。 $650^{\circ} \mathrm{C}$ 恒 温変態に於いては，パーライト・ノーズに近いため変態 開始時間は非常に短時間側に移行し, 変態速度も増加す るために完了も短時間内に起る。乙の $650^{\circ} \mathrm{C}$ 恒温変態 の際には光学顕微鏡では初所フェライトの析出は認めに くいけれども電子顕微鏡では写真 1 (a) のように認める ことが出来る。

てのように初析フェライトの析出は近傍のオーステナ イト中の炭素濃度を富化するとととなり, 従ってそてに $\mathrm{Fe}_{3} \mathrm{C}$ の核老生じ $\mathrm{Mehl}^{2}{ }^{3)}$ の提唱した機構に基いてそ の $\mathrm{Fe}_{3} \mathrm{C}$ 核と平行にフェライト屏が交互に析出している のがての写真からも明らかである。写真1(b) は extrac- 


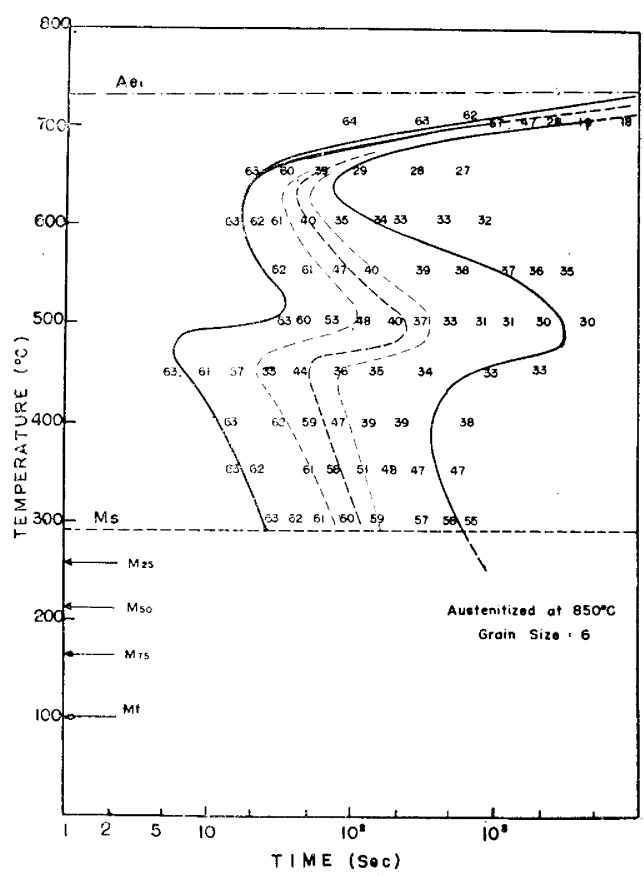

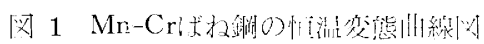

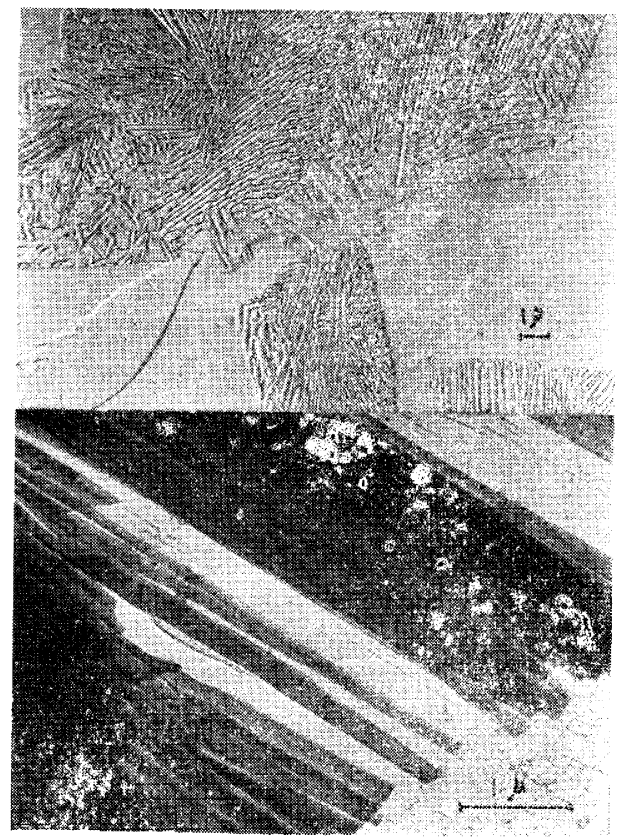

(a)

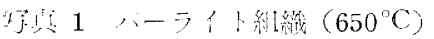

tion replica によるハーライト10 F $\mathrm{e}_{5} \mathrm{C}$ 交示してい

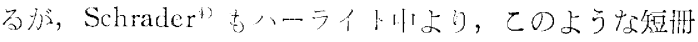
状の $\mathrm{Fe}_{3} \mathrm{C}$ 崖打们している。

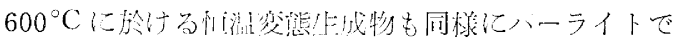

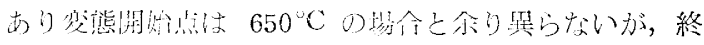

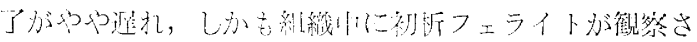

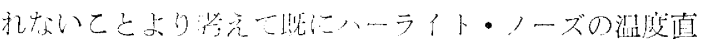

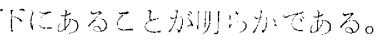

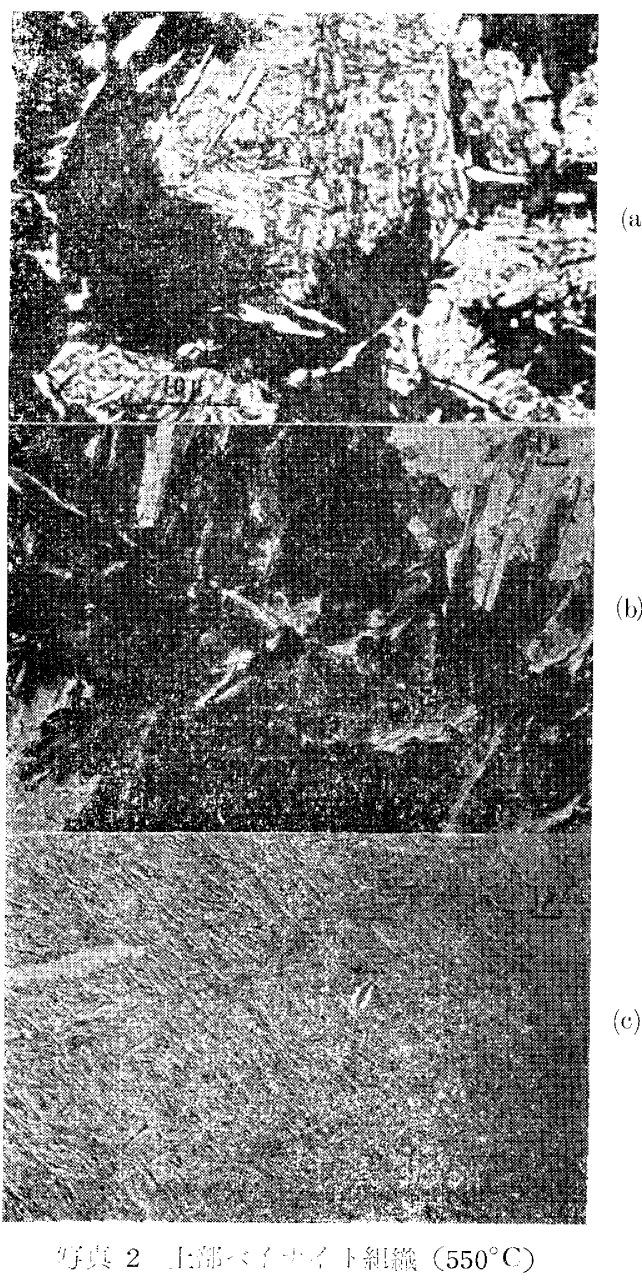

次に $550^{\circ} \mathrm{C}$ -

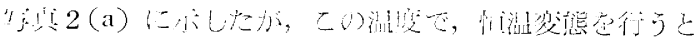

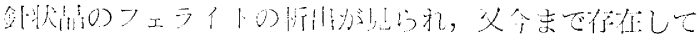

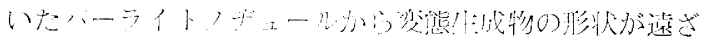

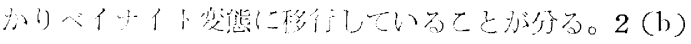

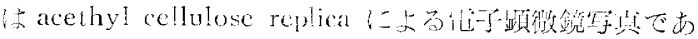


り，圆状組織より村毛状維綵に变化し，同一コロニー內

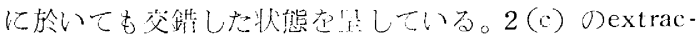

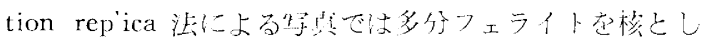

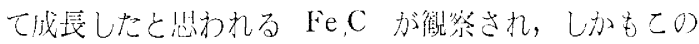

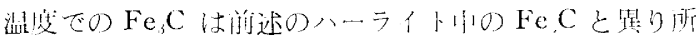
拥上部べイナイト域に於いては将巨状寺六つているが,

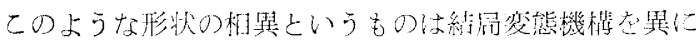
するためであると济充られる。

父 $\mathrm{Fe}_{3} \mathrm{C}$ の大ささの点でもハーライトのそれよりも却

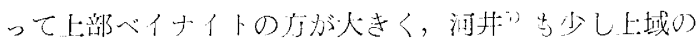
滥骨で生成したハーライト川のFeＣＯ方が微細でする こと琶めている。

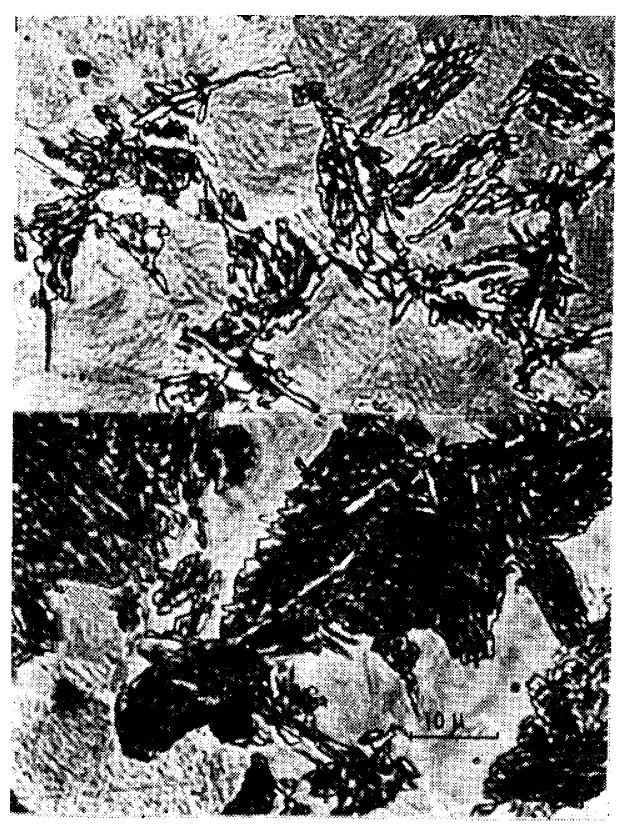

写突 3 上部べイナイト組織 (a) $500^{\circ} \mathrm{C}$, (b) $450^{\circ} \mathrm{C}$

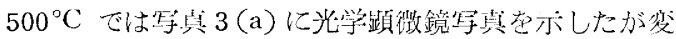
焦初期に於いてはしのようにフェライトが成長するため

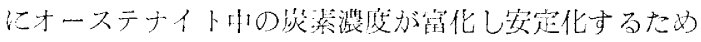
変態進行は非常に緩慢となり図 1 の㑑温変欵曲線図に於

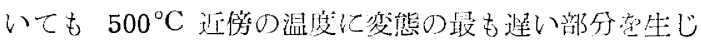
る。しかし恒温変態温度が降下すると, 変態開始点はべ イナイト・ノーズのために左侧に移行し，父変態終了点

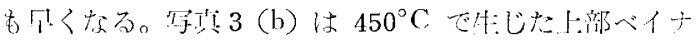
イトである。

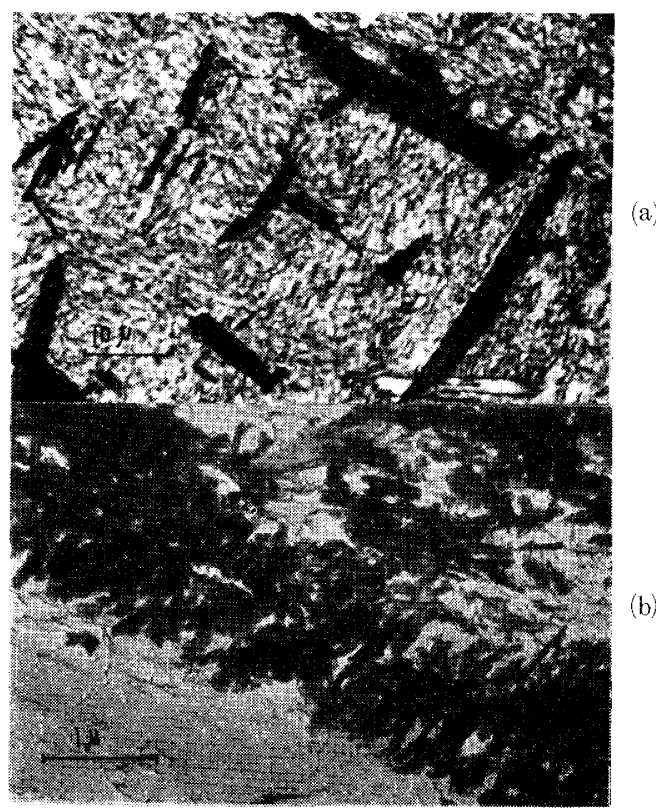

写点 4 下部べイナイト組織 $\left(350^{\circ} \mathrm{C}\right)$

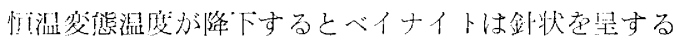
ようになり $350^{\circ} \mathrm{C}$ での㑑沾变热過稆の光学顕微鏡組織

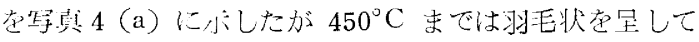
いたにも㧦ず $400^{\circ} \mathrm{C}$ 以下では剑状に変っている。 4 (b) は extraction replicaによる霆子顕微鏡写真であるが下 部べイナイト域に於いて観察される炭化物は上部領域に 抢けるものと形状的には大差はないが $\mathrm{Fe}_{3} \mathrm{C}$ の大さの 点では相当に微紐な $\mathrm{Fe}_{3} \mathrm{C} の$ 集合組織であるてとが分る が，これはべイナイト核が多数所出したこと等に基因し ている。

これ等炭化物の結昆㩐進は $\mathrm{X}$ 線回折の結果によると $\mathrm{Fe}_{3} \mathrm{C}$ だけしか琹めら狄なかったが，乙の $\mathrm{Fe}_{3} \mathrm{C}$ 中には 当然 $\mathrm{Cr}, \mathrm{Mn}$ 等が涉縮していると推定されるが, Bower 6によれば Fe 中の Cr 固溶量が $20 \%$ 程度になると新た に $\mathrm{Cr}_{7} \mathrm{C}_{3}$ なる $\mathrm{Cr}$ の特殊炭化物の析出の起ること孝趣

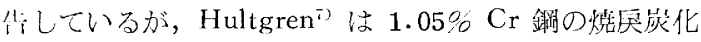
物中でも平衡 $\mathrm{Cr}$ 量は10\%にも達しないてとを報告して いる。

\section{$3.2 \mathrm{Ms}$ 点}

Greninger一Troiano 法によって，急冷浴の温度が200 ${ }^{\circ} \mathrm{C}$ 以上の際には金属浴 $(\mathrm{Pb} \mathrm{Sn})$ を棜い, $200^{\circ} \mathrm{C}$ 以下

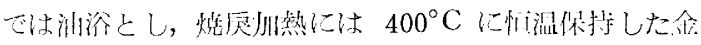

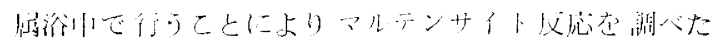

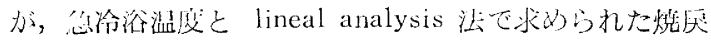


マルテンサイト量との関係を図 2 に示した。Ms 点を決 定するには各測定点より $0 \%$ 焼杘マルテンサイトに相応 する温度を外㧴することにより求められた。尚この図に 扣いて $200^{\circ} \mathrm{C}$ 附近の温度では冷却剂の相異によって同 一温度でも生成マルテンサイト量に差が恝められるが, 油を冷却剂として使用した時には金属浴中に急冷したも のよりも低值をとり，ての近傍の温度に保持された油の 冷却能は相当に低下しているものと考えられ, 従って武 片が燒入された場合にマルテンサイト域での冷却速度が 遅くなり,そのためにオーステナイトの安定化が起り生 成マルテンサイト量が減少したものと考えることが出来 る。しかし作ら, 油浴も低温度になるに伴い各剆定点が 曲線上に乗るようになることは低温度に保持された油浴 の冷却能は比較的に良好であると思われる。この方法に
よる Ms 点の測定について Ramachandron et $\mathrm{al}^{8)}$ が油 浴と塩浴について $180^{\circ} \mathrm{C}$ 附近で同じく生成マルテンサ イト量に差異のあること報告して扣り，ての原因とし てマルテンサイト域に拈けるオーステナイトの安定に基 くものであると結論している。図 2 よりも明らかなよう に，この $\mathrm{Mn}-\mathrm{Cr}$ 鋼では油中に焼入を行った際には常 温近くに㨟いても $4 \%$ 位の残留才ーステナイトが存在 し，浴温が $100^{\circ} \mathrm{C}$ 位に低下してくれば生成マルテンサ イト量が飽和值に達する。この飽和点をもって Mf 点と し, 図 1 の恒温変態曲線図の Ms 点以下の温度に M25, $50 ， 75$ として示したのは図 2 の曲線よりマルテンサイト $25,50,75 \%$ 生成する温度を求めて記入したものであ る。

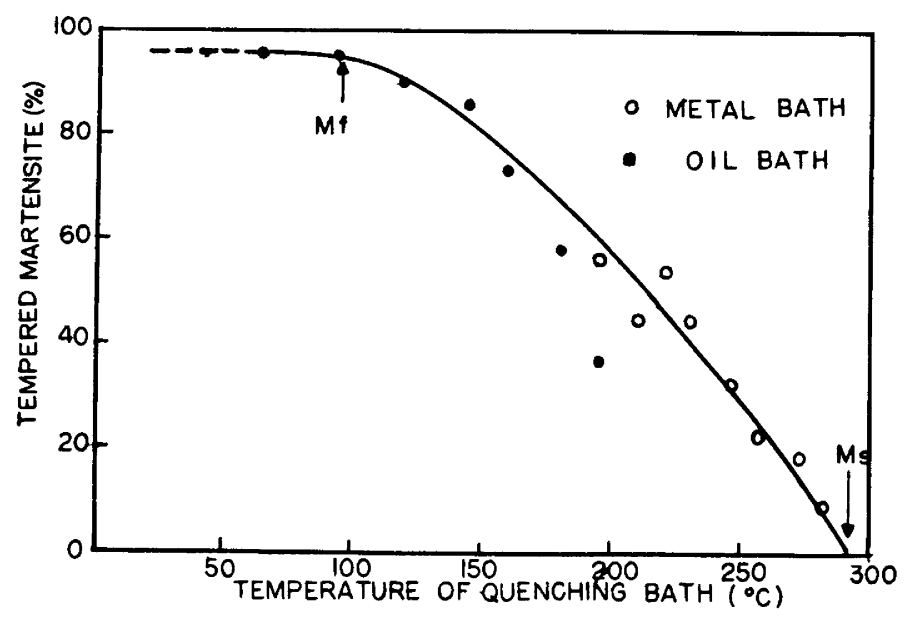

図 $2 \mathrm{Mn}-\mathrm{Cr}$ ばね鋼のマルテンサイト変態図

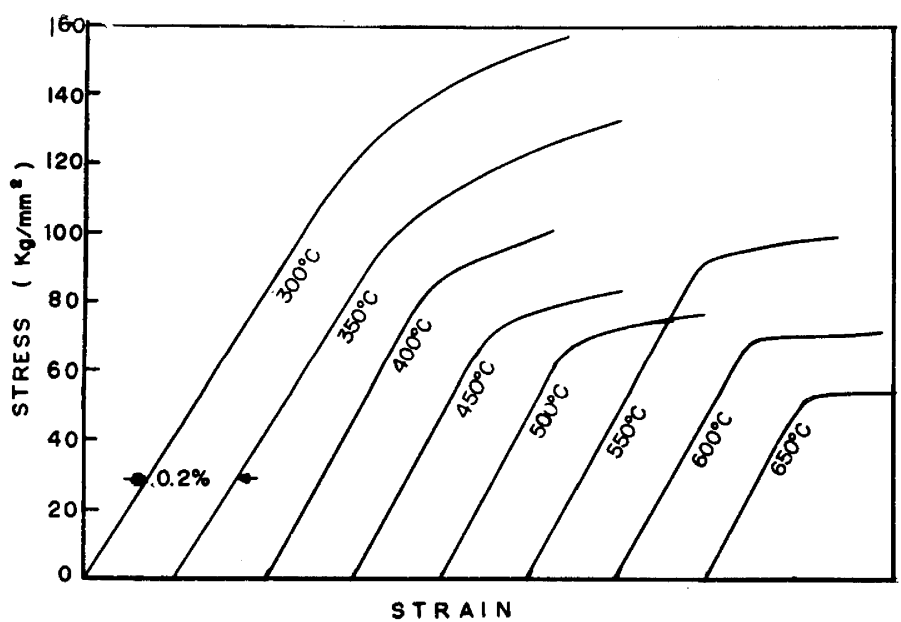

図 3 恒温変態処理試料の応力一霆曲線 


\section{3 恒温変態主成物の機械的性質}

恒温変態温度と各種機械的性質との関係を知るために やはり $850^{\circ} \mathrm{C} \times 30 \mathrm{~min}$ のオーステナイト化後 Ms 点直上 の $300^{\circ} \mathrm{C}$ 加 $650^{\circ} \mathrm{C}$ までの $50^{\circ} \mathrm{C}$ 毎の各温度で夫々 変態完了後水冷した試料について測定した。

引張試験では直径 $7 \mathrm{~mm} \phi$ で JIS 規格 2 号試験片を作 成し, 降伏点測定のため図 3 に示した応力一歪曲線を描 くととにより $0.2 \%$ 伸びの点から求めた。

$300^{\circ} \mathrm{C}$ から $650^{\circ} \mathrm{C}$ までの各温度で得られた恒温変態 生成物の機械的性質を図 4 亿示す。硬度の時間的変化は 図 1 亿数值を付記したように変態完了後の変化度合は非 常に少ない。しかし温度を函数とする場合には300〜 500 ${ }^{\circ} \mathrm{C}$ の間では，温度上昇に伴って低下し，組織的には針 状より羽毛状に移り析出炭化物は大きくなっている。と ころがこの上部べイナイト域の 500〜 $550^{\circ} \mathrm{C}$ に扔いては

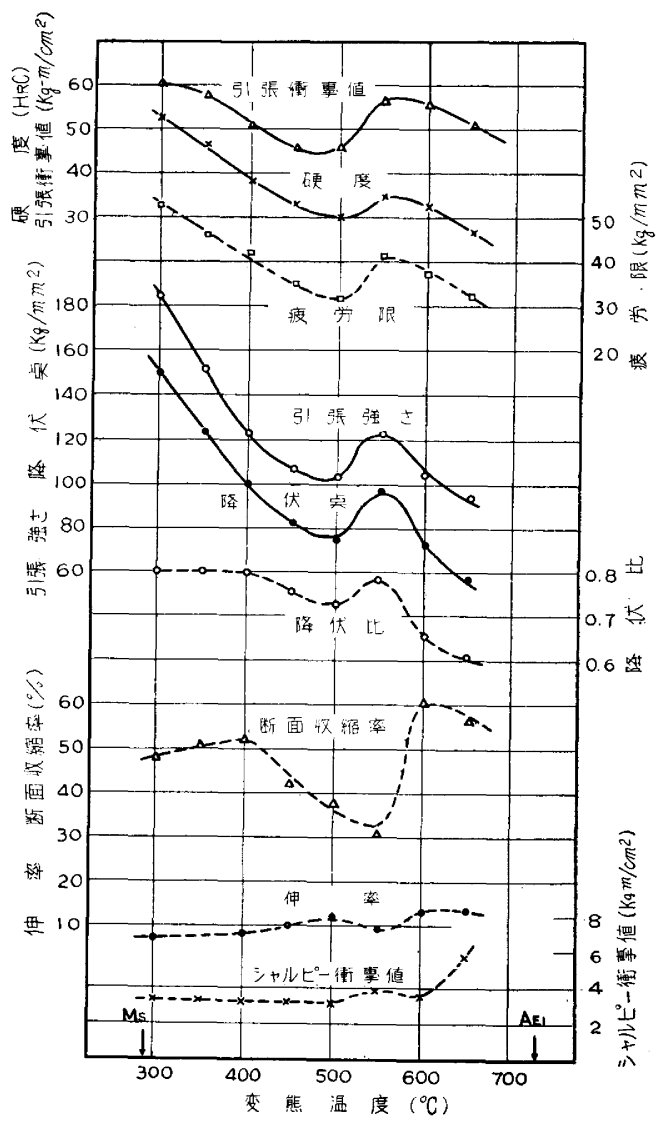

図 4 恒温変態温度と機械的性質

図 4 に示されているように一旦上昇する。しかし更に恒 温変態温度が上昇すれば硬度は再び低下し組織的には，
パーライト生成物に移る。

ばね鋼では spring hardness と称して硬度が, 各機 械的性質を知り得る手段とされているために恒温変態処 理された場合に扣ける関連性を知るために図 5 亿硬度 (ロックウェル C) を函数として呈示した。引張強度は 変態温度に関しては硬度変化と同じ挙動走示し下部べイ ナイトより上部べイナイト域まで急激に低下する。上部 ベイナイト域ではやはり異常性が観察され写真 $3(a)$ に 示されている $500^{\circ} \mathrm{C}$ 恒温変態生成物が低強度を呈する。 そして恒温変態温度が上昇すると再び低下し，パーライ 卜組織中に初析フェライトが観察されるようになると一 層低下し始め結局上部べイナイト域でループが生じる。

このように上部べイナイト域に扣いて異常変化の起る ことを Delbart ${ }^{9)}$ ，Davenport ${ }^{10)}$ ，Potaszkin ${ }^{11}{ }^{12)}$ 及び 河井 ${ }^{5)}$ 等が炭化物形成元素を含有する特殊鋼を恒温変態

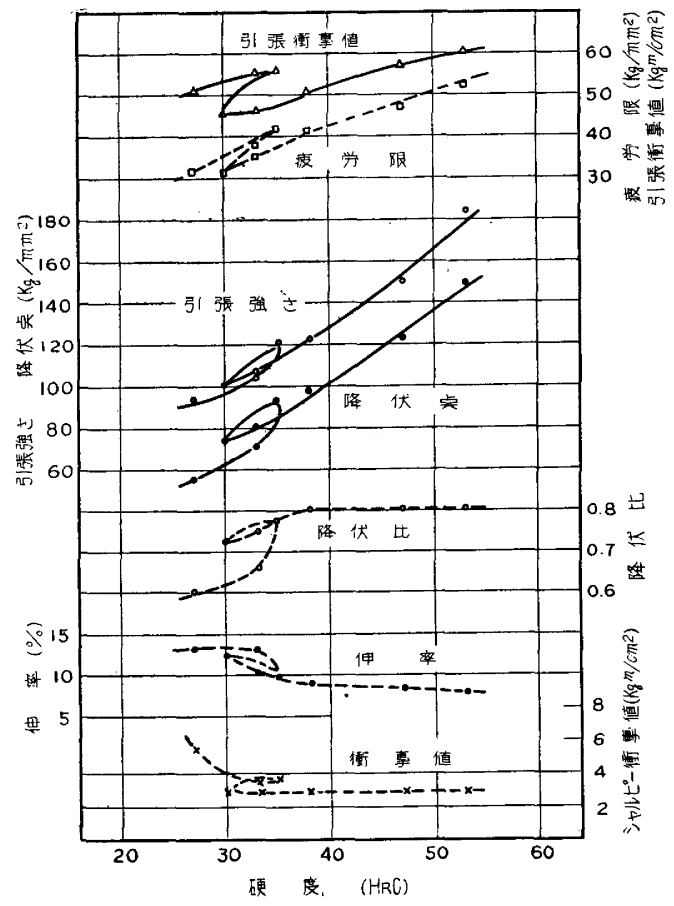

図 5 硬度と機械的性質

処理した際に起ることを報告している。河井によるとこ れ等鋼種のものでは Jominy 試験に招いても異常性の現 われるととを認めている。

本研究でも $\mathrm{Cr}$ 等の炭化物形成元菜を含んでいるため に，乙の種の現象が観察されたが一般に炭素量の多い程 顕著である。

$550^{\circ} \mathrm{C}$ での変態未完了試料の組織は写真 2 に示した 
extraction replica の写真のように上部べイナイト組織 であるが硬度・引張強度変化の挙動に拁いてはパーライ 卜的な挙動を示す。乙の $550^{\circ} \mathrm{C}$ で変態完了した武料に ついては，その組織上の区別は困難であるが，パーライ ト組織と上部べイナイト組織が共存するととも考光得る のである。5140鋼の恒温変態に搃いて Troiano ${ }^{13)}$ が 540 ${ }^{\circ} \mathrm{C}$ での膨脹測定で 2 段階に変化が現われることを琶め, 初期のものはべイナイトによるものでその後にバーライ 卜変態による膨脹が起り温度に関しては両者は混合する が時間的には両変態は分離することを報告している。そ れ故この $\mathrm{Mn}-\mathrm{Cr}$ ばね鋼の $550^{\circ} \mathrm{C}$ 恒温変態の場合につ いても変態末期に一部バーライトが生じたと考えるのが 罗当のようである。降伏強度についても引張強度と同様 な挙動を示すにも拘らず図 $\mathbf{5}$ の硬度を函数とすると引張 強度は硬度と直線的と見做されるが，降伏強度について は低硬度域では可成り直線より下迴る。バーライト組織 では強度が硬度に比して此較的低いてとは図 3 の応力一 歪曲線から明らかなように弾性変形後の塑性変形が顕著 に現われているためである。

一方べイナイト組織では弾性限も比較的に大きく又塑 性変形への移行が顕著に現れていない。以上の絬果は図 4 の降伏比変化が下部ベイナイト組織では $80 \%$ であるに 拘らずパーライト組織では非常に少下し $60 \%$ 程度しか得 られない。恒温変態処理により機械的性質が上部べイナ イト領域で変化が不規則となり, 従って相互関係を図示 した際には強度変化の逆行により完全な比例関係にない 場合にはループを描くことになる。

破断伸びに関しては当然変態温度上昇に伴って増大し ているが，その度合は非常に少ないけれぞも硬度との関 係では高硬度部では大体一定であっても $\mathrm{H}_{\mathrm{L}} \mathrm{C} 35$ 以下の 部分では可成り変化があり，バーライトでは図 5 の如く 13\%に達する。

断面収縮率ではパーライト組織が勿論良好であるが硬 度等の変化でパーライトに近い挙動を示していた $550^{\circ} \mathrm{C}$ 恒温変態生成㸮が最低の断面収縮率を示し, 変怤温度が 降下するに従って断面収縮率す徐々に增大し下剖べイナ イトで汢大体一定值京取るようになり, 絬局上部べイナ イトが図4 亿示されているように相刘的に低くなる。硬 度との関連は全く系統的でなく，恒温変態処理材の断面 収縮変化は変態生成物の組織にのみ密接なる関連性を認 めるととが出来る。この点が硬度, 引張強度等の変化と 趣を異にしている。

U-notch-Charpy 衝撃試験では $300 \sim 600^{\circ} \mathrm{C}$ の間で
は余り変化はないが $650^{\circ} \mathrm{C}$ になると急激に衝撃抵抗が 図 4 のように大となる。0.4\% C の構造用鋼 ${ }^{14)}$ を恒温変 態処理した時にはしばしばての上部べイナイト域で顕著 な抵抗值の劣下は認められなかった。

平行部直径 $6 \mathrm{~mm} \phi$ の試験片を用いての引張衝撃武験 結果も同じく図4 亿示したが，乙の場合にはやはり上部 ベイナイト域での值が低く下部べイナイト域では比較的

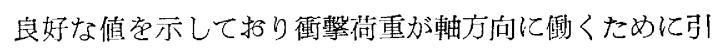
張強度も大いに影響していると思われ, 又抵抗值が曲げ 衝撃值に比して高いことは, 軸に直角方向よりも軸方向 に刘する抵抗方が大きいてとが原因である。硬度と比較 せる場合には低硬度側で図 5 の如く直線より高い值を示 す。結局この引張衝撃に抢ける值汃ら勒性を諭じるのは 不適当であることは Kenneford ${ }^{(5)}$ の結果からも筧える。

シェンク両振据り疲労の結果を図4 亿示したが，試験 片は直径 $6 \mathrm{~mm}$ に仕上研磨したものを使用した。との 図より明らかな如く疲学限は高硬度尔有する材料程高い けれども endurance ratio を考光た場合には $\mathrm{H}_{\mathrm{h}} \mathrm{C} 50$ 以 上ではての值は低下して 0.3 以下となるが，その他の場 合には0.33〜0.35の值に落着いている。疲学限に対して は初所フェライトの析出が見られる場命には好ましくな い。一般的に，ばね鋼が実際使用されている場合には疲

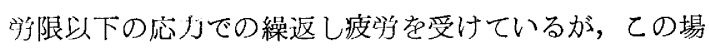
合でも結晶歪を生じ降伏点の変動, 及び衝撃抵抗の軽減 を生じるものと考えられる。

\section{4. 結}

1） $\mathrm{Mn}-\mathrm{Cr}$ 鋼 の恒温変態曲線図では連続冷却に際し てはべイナイト変態の比較的に生じ易い形状をして拓 り，又パーライト・ノーズは右側に寄っているので焼入 性に括いて好都合である。

2） $\mathrm{Ms}$ 点以下の $200^{\circ} \mathrm{C}$ 近傍の油浴中に急冷を行った 際には冷却能の低下によりオーステナイトの安定化現像 が起る。

3）この鋼では恒温変態処理した試験片の機械的性質 は上部べイナイト域で異常変化を示す。

4）硬度と引張強度及び疲学限の相互間では略々此例 関係を示す。降伏強度はべイナイト域では硬度と比例関 係に保たれているが，パーライト域では降伏比の劣下が 琶められ比例が保たれなくなる。

5）䩲性については, 衝撃值は低温での恒温変態でも 好結果を示し顕著な変化は認められない。一方断面収縮 率は上部べイナイト域では著しく低下しているが下部べ 
イナイトになるに従って回復し, 又パーライトは好結果 を示し組織敏感性を示す。

\section{文献}

1) J.H Hollomon et al : Trans. A.S.M. 38 (1947) 807 847

2) R.F. Mehl : J. Iron \& Steel Inst. 159 (1948) 113 129

3) R.F. Mehl : Rev. Mét., 54 (1957) 245 256

4) A. Schrader et al : Arch. Eisenhütenw. 28 (1957) $461 \sim 468$

5）河井：鉄と鋼 39 (1953）1159 1165

6) J.E. Bower : J. Iron \& Steel Inst. 183 (1956) 268 274

7) A. Hultgren : Rer. Mét. 50 (1953) 847 867
8) E.G. Ramachandron \& C. Dasaratly : J. Iron \& Steel Inst. 192 (1959) 268

9) G. Delbart \& R. Potaszkin : Rev. Mét. 43 (1946) $84 \sim 94$

10) E.S. Davenport: J. Metal 9 (1957) 677 688

11) R. Rotaszkin \& M. Jaspart : Rev. Mét. 48 (1951) 314 327

12) R. Potaszkin \& K. Baravi : Rev. Mét. 55 (1958) $345 \sim 363$

13) A. Troiano : Trans. A.S.M. 41 (1949) 1093 1112

14）河井，井上，小川：鉄と鎆 39 （1953）716 722

15) A.S. Kenneford: J. Iron \& Steel Inst. 188 (1958) $16 \sim 22$

[抄録]

強化プラスチック板ばねの設計

L. A. Heggernes, Prod. Eng.

Vol. 30 (1959), No. 46, P. 74

ガラス織維をゆるく編んで束にし，てれとエポキシ樹脂とで加圧成型した強化プラスチックは，すぐれたエネルギ 吸収材であって，ばね設計者にとって注目すべき物質である。ガラス繊維方向を曲げ応力向に対して，同一にとった もの，直角にとったもの，拓よび等方的に並べたものの 3 種類について，ガラス繊維 $65 \%$ ，エポキシ樹脂 $35 \%$ の強 化プラスチックを例にとり，SAE 1060 銅との比較を表示してある。それによるとばね材としては繊維方向と応力方 向とが同じものが最良で, SAE 1060 鋼に対して曲げ強さ 0.6 倍, ヤング率 0.16 倍，エネルギ吸収量 2.5 倍，耐久 限度は 0.9 倍となっているから，使用目的によってはばね鋼に取って代われるものである。また強化プラスチックは， 窗蝕の恐れがなく，切欠に対して鈍感である上に，振動は早くしかもなめらかに消减するのでコンベヤーや振動膜く の使用に適している。設計方法については，最小曲げ応力に対する厚さ，最大組合せ応力と最大許容応力との関係， 危険座屈応力など 6 段階に分けて，計算例を示して説明している。一般に強化プラスチックは高温に対しては，その

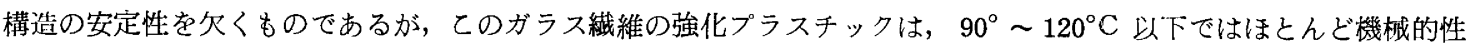
質が変らないから，一般の使用には差しつ加えないとしている。

(斎 藤 郁 夫) 